\title{
A discourse analysis of the second Aristotelian canon, arrangement, in the selected speeches of Bishop Dumeni
}

\author{
Petrus Angula Mbenzi ${ }^{1}$ \\ University of Namibia
}

\begin{abstract}
This study investigates arrangement in the speeches of Bishop Kleopas Dumeni. The paper hinges on an Aristotelian theory of rhetoric. Aristotle divides arrangement into the following components, exordium (introduction), narratio (statement of facts), partitio (division), confirmatio (proof), refutatio (refutation) and peroratio (conclusion). These components of arrangement were used to evaluate arrangement in the speech of Bishop Kleopas Dumeni. Bishop Dumeni conducted various speeches calling for the independence of Namibia from 1979 to 1988. However, the speeches of Bishop Dumeni were not subjected to analysis to reveal how his speeches were organised to woo the audience to his side to support him in his decolonising efforts. Content analysis was used to dissect the speeches of Bishop Dumeni to identify the elements of arrangement in these speeches. The study reveals that Bishop Dumeni effectively used the elements of arrangement as expounded in Aristolean theory.

\section{Introduction}

Bishop Kleopas Dumeni led the Evangelical Lutheran Church in Namibia (ELCIN) from 1979 to 2000. He served as the Church leader in Namibia during the critical stage of the liberation struggle. ELCIN together with other churches in Namibia actively participated in the liberation struggle through passive resistance strategies. They teamed up with church world organisations calling on the international community to pressure South Africa into accepting the implementation of the United Nations (UN) Resolution 435 thereby paving the way for the freedom of Namibia. Bishop Dumeni conducted many speeches nationally and internationally calling for the independence of Namibia.

This paper investigates the Aristotelian canon of arrangement in the selected speeches of Bishop Dumeni from 1979 to 1988 . This period was selected because the fight for the liberation struggle both diplomatically and militarily became intensified. The aim of this paper is to dissect the speeches of Bishop Dumeni to establish how his speeches were organized "to ensure maximum persuasive effect" (Brothers, 1997, p. 2).

Charteris-Black (2014) argues that, "We may think of arrangement in terms of the distinct stages or parts of a speech, and how the sequence of these parts could influence an audience" (p. 16). Cicero and Quintilian identified six parts of arrangement: exordium, narration, division, proof, refutation and peroration (Nordiquist, 2017). The arrangement of speeches of Bishop Dumeni is identified based on the six stages.
\end{abstract}

\footnotetext{
${ }^{1}$ Petrus A. Mbenzi is an Oshiwambo senior lecturer at the University of Namibia in the Department of Language and Literature Studies. He holds an MA and PHD from the University of Kwazulu-Natal and University of Namibia, respectively. He has specialized in Literature and Rhetoric and has authored several school books. His research interests include lexicography, literature, and onomastics and ethnoscience. Email: pmbenzi@unam.na
} 


\section{Exordium}

This subsection presents the types and nature of introduction to the speeches of Bishop Dumeni. The subsection also provides the definition and purpose of an introduction. The preludes to introduction are presented, and such prelude may include invocations or salutations.

Aristotle (1991), Quintilian and Cicero (as cited in Nordquist, 2017), Kangira and Mungenga (2012), and Mwangi (2009) express similar opinion that the aim of the exordium is to capture the minds of the listeners and to provide the purpose of the speech. Steinberg (as cited in Mathe, 2006) lists five types of introductions: "an anecdote; a startling statement; a quotation; a humorous statement and a rhetorical question" (p. 194). It is important to find out whether Bishop Dumeni used any of the types of introduction as suggested by Steinberg.

The speeches of Bishop Dumeni were often characterised by invocation. Mbiti (1969) defines "invocation as common versions of prayer used by Africans" (p.65). Mbiti further states that "invocations are short and spontaneous form of prayer asking God to intervene for a particular purpose." "Invocations are, however, a worldwide form of worship, because it is an act of asking for help from a god or a person who has power. It also includes a prayer at the beginning of a public ceremony" (Macmillan English Dictionary for Advanced Leaders, 2001, p. 758).

In analysing the speeches of Bishop Dumeni, invocation mainly served as a prelude to introduction. Being the head of ELCIN, Bishop Dumeni began his speech with an invocation combined with salutation when he addressed the local audience and international audience, for example, when he addressed the audience at the LWF pre-assembly held in Harare from 7-16 ${ }^{\text {th }}$ December 1983, he said:

Mr. Chairperson, honorable delegates, brothers and sisters. I would like to greet you all in the name of Triune God, the Father, Son and Holy Spirit.

In the above address, there is a combination of invocation and a protocol type of salutation in which he addressed the chairman followed by honourable delegates. He placed the chairperson on the highest pedestal as he repeated 'Mr. Chairperson' more than three times and, 'honorable delegates' and "brothers and sisters" were repeated twice. Repetition here was used to keep the audience attentive and to call on the delegates to support the cause for the liberation of Namibia. Bishop Dumeni used the ethos of the dignitaries to show that the assembly was important.

The length of the salutation by Bishop Dumeni depended on the type of audience he addressed. When he addressed the local audience particularly the members of his church, ELCIN his salutation was short: Dear brothers and sisters or Dear listeners. This is evident in his speech at the funeral service of Rev. Fredrik Nghihalwa, and the funeral of the victims of the Oshakati bomb blast.

The common words and phrases of Bishop Dumeni were: Your excellencies, comrades and friends, brothers and sisters, honorable members, your grace, and so on. These words of respects are common in his international addresses. The phrase he often mentioned last was 'brothers and sisters'. The use of this phrase is linked to his profession, because in addressing the parishioners or worshippers, a cleric always opens the service with this phrase. He thus stuck to the use of this phrase even when he addressed a non-religious gathering. It is not known why he pushed this phrase to the end of his salutation, but it can be assumed that he intended to address his audience according to a hierarchy as brothers and sisters seemed to refer to the people of lower rank. 
On the contrary, the salutation: comrades, appeared only once in Bishop Dumeni's Kabwe speech in Zambia in 1988. The meeting was between the members of SWAPO's external wing and the Namibian delegation. The word 'comrade' was a part of South West Africa Peoples Organisation (SWAPO) slogan such as 'Viva comrades' and it was a common salutation during SWAPO assembly.

The word 'comrade' seemed to have been popular in the $19^{\text {th }}$ century in Russia as evident in the work of George Orwell: Animal Farm in which Major, one of the characters repeated it ten times in his address to the other animals (Orwell, 1946).

SWAPO had connections with Communist-cum-socialist countries such as Cuba and Russia who commonly used the word 'comrade' as a form of address and had adopted their political slogans. Bishop Dumeni used the word purposively to establish consubstantiality with the audience which mostly included SWAPO supporters and members.

Here, Bishop Dumeni wanted to keep the audience attentive and also give reverence to the language of SWAPO. He persuaded his audience by using the stylistic identification in order to cause his audience to identify with his interest (Burke, 1969). Despite using the SWAPO language, he did not abandon his theological stand because he referred to his audience as brothers and sisters and friends respectively. This form of address was adapted from the Apostle Paul style of address to his congregation. Paul referred to his people in his letters as brothers

Although he quoted from the Bible in Kabwe, Zambia in 1988, The Biblical verse was followed by salutation.

The peace that Christ gives is to guide you in the decisions you make. Col. 3:15

Master of Ceremony,

Your excellencies,

The president of SWAPO, Dr Sam Nujoma,

Members of the Central Committee of SWAPO,

Guests from abroad, kings and headmen

Brothers and sisters, friends.

On behalf of those Namibians we have travelled here allow me to say a few words. It was indeed a great honour to have these proceedings opened by his honour the Secretary General. We are most grateful to you sir for doing so and to your country for hosting this important gathering. We, Namibians, deeply appreciate the friendship and hospitality which your country has so unselfishly extended to our people.

Here, Bishop Dumeni employed the rhetorical device known as expletive. Expletive "is a word or phrase in a sentence that does not contribute to meaning, but sustains the thought of sentence (Crystal, 2011, p. 179). These empty words were used to draw the attention of the audience to the fact that the meeting was attended by very important people who deserved recognition for their attendance. Here, Bishop Dumeni used honorific terms to show respect to people of different statuses. Leech (as cited in Aremu, 2011) defines "politeness principles as verbal and non-verbal behaviour that maintain harmonious relations" (p. 134). Leech further states that politeness is often relative to people and their culture expressed through language. In the Oshiwambo culture words of deference play an important role in conversation. By addressing the delegates by titles of honour, he seemed to pay homage to his culture in which such language is revered. 
In the salutation, Bishop Dumeni avoided mentioning the names of the leaders. Mentioning the names of the leaders or adults in conversational situation is seen as taboo in Oshiwambo culture. The chiefs and other leaders are always addressed by their words of respect. Bishop Dumeni seemed to have adopted the same attitude of addressing leaders by honorific terms such as Master of Ceremony, Your Excellencies, and so on. However, he digressed from the norm when he said: The president of SWAPO, Dr Sam Nujoma. This is against the Oshiwambo norms, because personal names of prominent leaders are skipped in the forms of address. This avoidance language is not confined to Oshiwambo culture only. The Zulu tribe of South Africa called this language 'ukuhlonipha', to respect. Avoidance speech, or "mother-in-law languages" is also a feature of many Australian Aboriginal languages and Austronesian languages and some North American languages and some Ethiopians (Crystal, 2011 \& Koopman, 2002).

The use of your country signified that Zambia had been very helpful and sympathetic to the liberation struggle of Namibia. The Zambian Government hosted the Namibian refugees during the struggle for liberation in Namibia.

The Biblical quotations by Bishop Dumeni at the beginning of his speech in Zambia were also observed in the speech of President Thabo Mbeki. On 11 January 2000, President Mbeki addressed the Centenary Synod of the Ethiopian Episcopal Church in Port Elizabeth (Mbeki, 2000). Mbeki started his speech by quoting the late President of the African National Congress, Oliver Tambo, who approached the World Consultation of the World Council of Churches in 1980 as follows:

So God created man in his own image, in the image of God created he him; male and female created he them. And God blessed them, and God said unto them, be fruitful, and multiply, and replenish the earth, and subdue it: and have dominion over the fish of the sea and over the fowl of the air, and over every living thing that move upon the earth Genesis 1, 27-28 (Mbeki, as cited in Tutu, 1983).

Like Bishop Dumeni, Mbeki chose to begin his speech with Biblical quotations because he deemed it fit the occasion. This type of introduction was determined by the circumstances. Beginning with Biblical verse appealed to the attention of the religious leaders in Mbeki's speech. The use of Biblical verse may serve as a persuasive tool. Gitay (2001) explains the significance of religion as a means of persuasion "Religion has been a strategy for delivering the message persuasively. The religious argument here functions as a means of persuasion" (p. 53).

Bishop Dumeni stated the purpose of his speech in the exordium in 1983 in Harare, Zimbabwe. "Mr. Chairperson, brothers and sisters at this juncture, allow me to share with you all some experiences with regard to the current situation in Namibia." Whereas Bishop Dumeni used invocations or salutations in other speeches, in his speech at Wartburg Theological Seminary in 1979, he did not use invocations, biblical quotations and salutations. He simply expressed his joy and stated the purpose of his speech:

It was a great surprise to me to receive the message of your honorable board of regent's decision to confer upon me THE DOCTOR OF DIVINITY DEGREE, HONORIS CAUSA. I felt then and I still feel today that I am not personally worthy of this honour. I decided however to accept your decision on behalf of my church.

Bishop Dumeni repeated the pronoun "l" to signify the personal achievement and the possessive 'your' to show his appreciation to the board of Wartburg seminary for deciding to bestow an honour upon him. 
In addition, there were some occasions where Bishop Dumeni avoided using invocation and Biblical quotations. It was not clear whether Bishop Dumeni did so deliberately or it was an omission. The types of audience he was addressing was similar to the type of audience he addressed in other places where he used invocations. He was addressing the audience at Gettysburg in the United States of America (USA) in 1987 and his audience consisted of theological and non-theological students:

May I say how pleased I am to be here with you in Gettysburg today. This is a historic place. This has been a place of Christian learning for more than hundred years. Many leaders of the church have been taught here and many leaders of your communities in teaching, arts, business and medicine. Gettysburg was once a place of war when brothers fought brothers because of the desire for one part of your country to keep alive the sinful practice of slavery. But now it is a place of peace, of learning, of preparation for future.

Bishop Dumeni contrasted war with peace to emphasise that there was a civil war in Gettysburg when the British oppressed the Americans. This is a reference to the American civil war between blacks and whites in 1683. The Americans treated blacks as slaves and blacks reacted against slavery. By saying many leaders of the church have been taught here, he was making the reference to the training of his pastors as well. Some pastors of ELCIN were trained at Gettysburg College.

Bishop Dumeni used a similar strategy in Canada, Ottawa, in 1986, where he used the expression of gratitude in his introduction. Bishop Dumeni began with the rhetorical device of ethos by describing the Canadians as helpful people who supported the Namibians morally and materially:

Greetings to our friends in the Church of God. We, your Namibian brothers and sisters wish to extend our gratitude for your welcome of our delegation and for all that you are doing on our behalf, both in moral and material support. You make us feel part of worldwide family.

Bishop Dumeni attempted to establish rapport with the audience by referring to them as brothers and sisters. Through the use of the words 'brothers and sisters', Bishop Dumeni tries to construct a global Christian identity. The phrase 'Church of God' shows that the Christians belong to a single community in the name of God. This means that Christians are all created by one God.

Throughout this subsection, it has become clear that Bishop Dumeni's introduction to speeches included Biblical verses, quotations, expression of gratitude, statement of purpose and thanksgiving.

\section{Statement of facts}

The statement of facts consists in the persuasive exposition of that which either has been done or is supposed to have been done or to quote the definition given by Appolodorus as a speech instructing the audience as to the nature of the case in dispute. In statement of facts the readers are informed of the circumstances that need to be known about the subject. Quintilian (as cited in Laurin, 2012, p. xxx). Quintilian also advised that this portion of the discourse be lucid, brief, and plausible. Bishop Dumeni often stated his facts clearly and briefly. In 1980, addressing the worshippers at the ruins of the ELOC printing press he said:

All of you who are gathered here today bear the testimony that, our service provider, the printing press of ELCIN is no more. The service and activities of the press has been ground 
to a standstill. The service was not only extended to Evangelical Lutheran OwamboKavango Church (ELOK) members, it was extended to all the Lutherans all over the world and it was also extended to our sister churches and friends who helped us to rebuild this press. This press does not belong to certain individuals as some people might think.

In the above discourse, the audience is informed that the service of ELOK printing press was delivered locally and internationally. By saying "This press does not belong to certain individuals as some people might think", he seemed to make reference to the representatives of the colonial authorities in the Owambo Administration who alleged that evil things came from Oniipa."Some claimed that the printing press belonged to Bishop Dumeni and the church governing council" (K. Dumeni, personal communication, July 20, 2011).

\section{Division}

According to Lawrie (as cited in Chissano, 2016), in division "the speaker states briefly what he or she is about to argue about or what line the speech will take" (p. 78). Kennedy (1999) clearly explains the meaning of partition in rhetoric:

The partition is of two parts: the speaker can state the material on which there is agreement with the opponent and what remains in dispute, or can list the points to be proved. In the latter event it is important to be brief, complete, and concise.

Similarly, Chissano (2016) argues that "in division the speaker names the issue in dispute" (p. 24). This stage appears in Bishop Dumeni's speeches. In his speech during the service at the ruins of ELOK printing plant in 1980, Bishop Dumeni names the issue in dispute namely the destruction of the ELOK printing press thus he said:

All of you who are gathered here today bear the testimony that, our service provider, the printing press of ELCIN is no more. The service and activities of the press has been ground to a standstill. The service was not only extended to ELOK members, it was extended to all the Lutherans all over the world and it was also extended to our sister churches and friends who helped us to rebuild this press.

Similarly, while addressing the LWF conference in Budapest in 1984, he mentioned the issue in dispute, the oppression of the Namibian people. At this conference he said, "My country is a country of suffering people: we are occupied illegally by South Africa and we are suffering under the brutal rule of apartheid, government enforced racism." He repeated the same strategy in Geneva in 1987: "The case of Namibia is still unresolved; the struggle for freedom, peace and justice which is the inalienable right of all the people of Namibia is still unabatedly going on." In the preceding speech Bishop Dumeni "states briefly what he or she is about to argue about or what line the speech will take" (Lawrie, 2006, p. 23). However, during the radio speech in 1988 after the Oshakati bomb blast, Bishop Dumeni listed the points on which to hang his arguments:

We have come together here having thought of two different kinds: We have come together in deep sorrow from the deaths of our beloved ones, to comfort one another and to encourage one another in faith. We have gathered also to express our sympathy and sorrow for all our injured ones. Some are at different hospitals. The others are at their homes nursing their wounds while some are among us here. We have come to pray to God to heal them and to strengthen them in faith.

In this speech, Bishop Dumeni mentioned the two aims of his speech namely to comfort one another for the loss of lives and to pray for those injured in the blast. 


\section{Confirmation}

Mwangi (2009) describes confirmation as follows:

Confirmation is defined as a core of discourse in which the argument is presented and proven. In other words it is the part of the speech that contains supportive arguments, that is the arguments in support of the speaker's position. It is the presentation of our arguments together with their corroboration. A speaker uses various techniques to help support what he or she is saying. He can validate evidence from the authorities by arguing that the authority had made a study, is trained in research, is freed from prejudice, and is free from exaggeration or consistent with his or her thinking (p. 10).

Confirmation is "central and represents the main body of the speech, that is, a further demonstration of the argument exposed before. It is in this part of the discourse principally that one adds all the material pertinent to the subject to strengthen even more the initial theme / idea" (Laurin, 2012, p. XXXI)

The speeches of Bishop Dumeni include various arguments such as desire for freedom, and effects of oppression and suffering. These arguments are presented and substantiated:

Bishop Dumeni showed in his speeches the desire for freedom and peace in Namibia. Bishop Dumeni regarded the dawn of freedom as the precondition for true peace and democracy in Namibia. Addressing Bishop Tutu and his wife, Bishop Dumeni claimed that, "No change has been made during the past years and People's aspirations are being demolished by frustration and no indication of solution to be reached in the near future. He supported this claim with these observations:

"We notice the escalation of war in our country, military buildup in terms of personnel and armaments, death and suffering of people day in and day out. The desired United Nations Security Council Resolution (UNSCR) is not yet put into practice."

In a similar situation, when he addressed the audience in Brussels in 1986, his argument was: the Namibians demand freedom and independence from South Africa. He substantiated this argument through the following comments:

In fact, I will miserably fail in my duty if I did not make it unmistakably clear here that we shall never retreat back in our demand for freedom and independence of Namibia, our country. I would like to clearly reiterate it here that there is no reverse gear in this vehicle, i.e. our resolute desire and determination in demanding our independence.

There is a shift from the first person singular, for example "l" to first person plural "we", in which Bishop Dumeni shows personal responsibility and collective responsibility respectively. He carried on using the two persons interchangeably to demonstrate the fact that people contributed towards the fight against colonialism in their individual capacity and collectively.

The speeches of Bishop Dumeni presented the prevalence of oppression and suffering in Namibia. In his speech at Wartburg in May 13, 1979, Bishop Dumeni said, "Injustice prevails. The basics of apartheid and discrimination are still there"

He substantiated this argument with his observation of the situation in Namibia. He observed that: 
The population of Namibia is a much divided one. We have now a country on the verge of or actually deep in civil war, with sons of the same mother fighting one another, a situation where it is difficult to trust in anybody. We live in a situation where power-hungry parties try to use all means in order to obtain opportunity to rule.

The 'we' in the above paragraph is inclusive, because it refers to the people of Namibia. It was meant to draw the attention of the audience that the people of Namibia suffered the same fate. Bishop Dumeni announced that apartheid and discrimination was the order of the day. By saying "the son of the same mother fighting one another," he made a reference to the fact that some blacks joined the colonial army and others joined PLAN. It was, therefore, possible for the sons to fight against one another while serving different forces.

In the same speech Bishop Dumeni advanced an argument that, "We are not liked by the government". He supported this claim by reminding the audience of what they hear and see in the media. He also reminded of them on the reported incidents about the actions taken against the church workers: "This you can see and hear in the media, especially on the radio, in speeches and in action against church workers"

In this case, the exclusive 'we' does not refer to the people of Namibia, but to his church, ELCIN. He appeared to illustrate that the church suffered a lot. Many church workers were thrown in jail for political reasons and some were physically attacked. Dumeni (as cited in Katjavivi, Frostin \& Mbuende, 1989) clearly illustrates the suffering of the members of his church:

In some parishes services have been disrupted in a rude manner by hindering parishioners going to church; some people had arranged to take their children to baptism, but on the way they were instructed by the army officers to climb into the army trucks without explanations or given reasons. Some pastors who intended to conduct services were also seized and detained that day, although it was obvious that that they are spiritual leaders, and were accordingly prevented from conducting services and other duties (p. 94).

Furthermore, in his speech at the ruins of the printing press at Oniipa in 1980 Bishop Dumeni provided a strong argument to back his claim about the suffering of the Namibian people:

We have really suffered. The cost of this damage estimated at R350-000-00. To rebuild this printing press today would cost us between R400-000-00 - R500-000-00. Most of the workers have lost their job as a result of this blast. Our clients have been robbed of the service though they did not commit any offence.

The 'we' here is used in the same sense as in the previous paragraph to refer to ELCIN members only. The Bishop appealed to the pathos of the audience when he said, "We have really suffered... Our clients have been robbed of the service though they did not commit any offence." Here, he wanted to emphasise that the attack was aimed at innocent people.

This subsection reveals that Bishop Dumeni makes several claims and provides the substantive evidences to prove his claims through examples, facts and valid reasons. The claims and supportive arguments were wholly meant to convince his audience to support the fight for liberation in Namibia.

\section{Refutation}

There are several definitions of refutation. "Refutation is a part of the speech where the speaker responds to variant or opposing arguments. The speaker attempts to devalue views that are 
different from those he or she is advocating" (Mwangi, 2009, p. 10). Rieke and Sillars (as cited in Van Eermeren and Garssen, 2009) view refutation as a way of both attacking other's argument and defending one's own. Van Eermeren (1996) makes distinction between weak and strong refutation. "In a strong refutation, one is to attack the stand point by showing that the proposition is unacceptable whereas the opposite or contradictory proposition is acceptable. In weak refutation, it is sufficient to cast doubt upon the attacked standpoint without a defense of the opposite" (p. 36).

Bishop Dumeni employs both strong and weak refutations in his speeches. Strong refutations appeared in Bishop Dumeni's LWF Speech in 1984. Bishop Dumeni refuted the allegation by the colonial government in South West Africa (now Namibia) that the establishment of Ministerial Council was geared towards bringing peace in South West Africa:

Actually the only development on the political scene thus far is the creation of the so-called Ministerial Council of 12 men under the leadership of Mr. Dirk Mudge on July 11980 granting as such executive power to that council and its Democratic Turnhalle Aliance (DTA) dominated National Assembly. It is quite clear to every one of us including the authorities themselves... For it will never bring peace to our war torn country. It is an institution that cannot bring the long desired peace to the people who very badly need it. It is doomed to be an end in itself in the long run (1980).

Bishop Dumeni here tried to provide counterarguments to his case in order to counter negative responses from his audience: "the institution of such a Council is not the answer to the Namibian problem at all for it will never bring the long desired peace to the people who very badly need it." Cockcroft (as cited in Niggard, 2004,) argues:

The author of text can successfully make use of the ethos appeal if he manages to foresee the negative reactions and responses which his audience will possibly have to the text. That way he can prepare for the situation beforehand and thus include arguments in the text that will forestall the negative reactions (p. 28).

Bishop Dumeni successfully employed his ethos to appeal to the pathos of the audience with the strong refutation: the institution is not an answer to the Namibian problem ... Here, he paints the gloomy picture of the council which he considered as a fruitless exercise in attempt to settle the question of Namibia. This suggests that the authorities were trying to brainwash the world into believing that all was well in Namibia.

In addition to strong refutation, Bishop Dumeni also made weak refutations on some occasions. Reacting to the Oshakati Bomb blast in 1988 through his speech, Bishop Dumeni used weak refutation to counter the allegations made by both SWAPO and the interim government. Both SWAPO and the interim government accused each other of being responsible for the blast. However, Bishop Dumeni exercised his diplomacy in this case and left the audience in doubt:

Kutya olye, kutya olye e shi ninga omutondi gwoshigwana shi. (Whoever is responsible for this [incident], whoever is responsible for this is an enemy of this nation.)

Bishop Dumeni did not entertain the views of any of the warring parties, thus showing his impartial attitudes. The warring parties were accusing one another of the responsibility. This kind of refutation is needed under certain circumstances, particularly if one does not have concrete evidence on this issue. In this case Bishop Dumeni could not heap blame on any warring party as there was no legal ground on which to hang his response. 
The interim Government claimed that SWAPO was indeed responsible for the blast and the colonial army revenged on SWAPO fighters by attacking the bases in Angola. The SWAPO Secretary for Information and Publicity, Hidipo Hamutenya claims, "SWAPO had nothing to do with the blast at Oshakati. The bombing is part of dirty South African propaganda campaign to smear the name of SWAPO."

Bishop Dumeni argued that he could not heap blame on a specific party, because he did not have concrete evidence, but God knows who was responsible for the blast and on the judgment day, the culprit will be condemned to eternal death (K. Dumeni, personal communication, July 20, 2011).

Bishop Dumeni repeated weak refutations when he addressed the audience during the mass service at the ruins of ELOK printing press on 14.12.1980. A member of the Owambo Administration claimed that SWAPO was responsible for the blast ( $K$. Dumeni, personal communication, March 12, 2011). Bishop Dumeni refuted the claim in the following manner:

The enemy has decided to stop the activities of the printing thereby denying the people the services meant for them. Who is is this enemy? This enemy is known to God. The enemy knows himself who he is. His cohorts who together with him made a joint decision to annihilate this press know why they did this.

This is weak refutation because Bishop Dumeni did not point a finger at any person. Again he created doubt in the mind of the audience. By saying "I do not know his face" seems to reveal the weakness in his arguments thereby portraying himself as an honest man who avoided making empty statements and acknowledge his limited knowledge on the subject. This is a powerful technique for building credibility, because it allows the audience to conclude that you have evaluated your position critically (Lunsford \& Rusziewicz, 2001). Obviously, Bishop Dumeni avoided heaping blame on anybody, because there was no concrete evidence as to who was responsible for the blast. Bishop Dumeni here exercised diplomacy because he did not hurt any of the warring parties.

It is revealed in this subsection that weak and strong refutations were part and parcel of Bishop Dumeni's speeches. He demonstrated weak refutation through the use of diplomatic language by creating doubts in the mind of listeners without showing any opposition to the allegations. Strong refutation is revealed through the statements that showed that the allegations made were unacceptable and deserved condemnation.

\section{Peroration (conclusion)}

Aristotle (1419b) refers to the conclusion as the epilogue and stress that the epilogue consists of four parts: to make the audience well disposed towards the speaker and ill-disposed towards the speaker's opponent, to magnify or minimize the leading facts, to excite the required state of emotion in the hearers and to refresh the memories of the hearers. In addition, Steinberg (1999) explains that "The goals of a conclusion are "to sum up and tie the main points together, to remind the audience why the information is important to them and to motivate them to think or act on the ideas presented" (p. 197).

There are different types of conclusion for any speech or narrative such as a question. Such a question could be rhetorical question or hypophora, a strong statement which forcefully states your opinion, a well known quotation from a famous person or song, open conclusion, an ending which allows the reader or listener to draw his own conclusion, predictive conclusion, which 
expresses some though about the future based on evidence, exhortation which challenges the readers or listeners to action, personal comment which expresses the lesson you have learned and summary, where main ideas are said in a different way. These types of conclusions mentioned appear in various speeches of Bishop Dumeni. Bishop Dumeni ended some of his speeches with the quotations from the Bible. The following examples illustrate quotations in the speeches as a conclusion: Addressing the audience through SWABC Oshiwambo' service after the Oshakati bomb blast in 1988, Bishop Dumeni concluded his speech with Biblical texts and the invocation:

I encourage you to remain steadfast in faith because to enter the kingdom of God one has to go through thick and thin (Acts 14:21). Paul and Barnabas preached the good news in Derbe and many people turned to Jesus, thereafter they turned to Lystra and Iconium and Antioch in Pidisia. The peace of God which passes all understanding, may keep your hearts and souls in Jesus Christ."

Bishop Dumeni used what Crowley and Hawhwee (1999) called honorific language. The adjectives such as gracious, merciful and compassionate showed that God cared for His people. Jesus here is treated with respect. Bishop Dumeni chose these adjectives in an excellent and appropriate manner. The speaker wanted to convey the message to the audience that the Lord would never abandon them.

In this conclusion, Bishop Dumeni switched from the first person "l" to the second person "you" to establish rapport with his audience. A student cited in Micciche (2004, p. 719) argues that Malcolm X's use of "you" in "not Just an American Problem but a World Problem" involved his African American audience in an intimate way:

Speaking in the second person helps urge audience members to personally take responsibility for creating a political change and becoming active participants in the revolt for racial equality ... (p.719).

By using the Biblical texts, Bishop Dumeni wanted to console the listeners and turned to Jesus for consolation during the time of grief. Bishop Dumeni used the adjectives such as gracious, patient and compassionate to portray Jesus as the source of their courage and consolation. The speaker used Jesus's ethos to show that despite the tragedy that befell the audience, there was indeed Jesus who is ever prepared come to their rescue.

Apart from using quotations as part of his conclusion, on some occasions he used summary for his conclusion. In the following examples summaries are used a as conclusion. This is found in the Kabwe speech:

May the Lord help us as we start this consultation, according to our respective responsibilities to work according to the norms of his will in order to build up his kingdom and a just society even in Southern Africa and particularly in Namibia. The greatest joy lies in the fact that: We all serve one God and all serve one man-kind, ourselves included! Thank you.

Addressing the British Parliamentarians in 1985, he ended the speech with rhetorical questions:

We would like to get our independence through resolution 435 of the UN.

What is really blocking this process?

Why is the will of the majority of the Namibians up to now not taken into account in determining the future of this country? 
In the above discourse, the speaker asked a plethora of questions to challenge the audience to give their opinion on the questions. By employing questions, Bishop Dumeni wanted to move the audience to a specific feeling to sympathise with his ideas and to help the Namibians gain their independence. On some occasions, Bishop Dumeni used the type of conclusion called predictive conclusion. Predictive conclusion is a conclusion which expresses a future action. Bishop Dumeni used the predictive conclusion in the speech at the reopening of the press at Oniipa in 1982:

The confession of believers who suffered for the truth should become mine and yours which says, "Whatever I do, I do it as a Christian and as an obedient child of Christ. I believe that God the Almighty will give me power and be merciful to me in future so that I will struggle to preach the true gospel. I will do my Christian duty to fight for justice, peace and faith. "God is our mighty fortress. I would like all of us to say, "God, the father, God the son and God the Holy Spirit is our mighty fortress. Amen.

The use of the future tense in the preceding paragraph shows that the speakers wanted the Christian audience to commit themselves to the future action. There is also an expression of hope that God will do what he has promised to the Christians. There is a promise by Christians that they will fulfill their Christian obligation to ensure that peace, justice and faith are maintained. The main aim of this conclusion was to draw the attention of the audience to the fact that the power of God is insurmountable.

This subsection revealed that Bishop Dumeni used various types of conclusion to end his speeches such as the use of quotations, rhetorical question and hypophora, summary, predictive conclusion and exhortative conclusion.

\section{Conclusion}

Bishop Dumeni effectively used the stages of arrangement to appeal to his audience to support him. All stages of arrangement such as exordium, (introduction), narratio (statement of facts), partitio (division), confirmatio (proof), refutatio (refutation) and peroratio (conclusion) are reflected in the speeches of Bishop Kleopas Dumeni. Speeches were organized in such a way that they drummed up support for the struggle for independence of Namibia. There are evidences of the three modes of persuasion namely, logos, ethos and pathos in the arrangement of the speeches meant to convince the audience to speed up the implementation of the UN Resolution 435 thereby paving the way for the total decolonization of Namibia.

\section{References}

Aristotle. (1991). Rhetoric: A theory of civic discourse. (Translated G. Kennedy, Trans.). New York: Oxford.

Aremu, M. (2011). A social pragmatic analysis of obituary announcements in English in Nigeria. Journal of the Nigeria English Studies Association, 14(2), 132-143.

Brothers, C. (1997). War and photography: A cultural history. London: Routledge.

Burke, K. (1950). A rhetoric of motive. Los Angeles: University of California.

Burke, K. (1969). A rhetoric of motives. California: University of California.

Charteris-Black, J. (2014). Analysing political speeches: Rhetoric, discourse and metaphor. Hampshire, UK: Palgrave MacMillan.

Chissano, L.P. (2016). A rhetorical analysis of first inaugural addresses of SamoraMachel, Robert Mugabe, Sam Nujoma and Nelson Mandela. Unpublished Master's thesis. University of Namibia. 
Crowley, S., \& Hawhee, D. (1999). Ancient rhetorics for contemporary students $\left(2{ }^{\text {nd }} \mathrm{ed}\right)$. London: Allyn and Bacon.

Crystal, D. (2011). A dictionary of linguistics and phonetics $\left(6^{\text {th }} \mathrm{ed}\right)$. Oxford: Blackwell publishers Ltd.

Dictionary of English. (2009). Retrieved September 12, 2012 from www.thefreedictionary.com/comrade

Gitay, J . (2001). Rhetorical analysis of Isaiah. San Francisco: International Scholars Publication.

Gitay, J. (2002). Rhetoric and truth: The South Africa scene. An African Journal of Philosophy, Xvi(2), 1-2.

Hitchcock, G. \& Hughes, D. (1995). Research and the teacher: A qualitative introduction to schoolbased research $\left(2^{\text {nd }}\right.$ ed.). London: Routledge.

Kangira, J. (2010). Mugabe' gravestone orations: Collective memory and nostalgia.Makamani,

Kangira, J. \& Mungenga, J. N. (2012). Praiseworthy values in president HifikepunyePohamba's epideictic speech marking Namibia's $20^{\text {th }}$ anniversary of independence. Journal for Faculty of Humanities and Social Sciences, 1(1), 109-116.

Katjavivi, P., Frostin, P., \& Mbuende, K. (1989). Church and the liberation struggle in Namibia. London: Pluto Press.

Kennedy, G. (1999). Classical rhetoric and its Christian and secular traditio. University of North Carolina Press.

Laurin, A.P. (2012). Classical rhetoric in Baroque music. Unpublished Master's thesis. Institution for Klassisk music.

Lawrie, D. G. (2006). Speaking to good effect: An introduction to the theory and practice of rhetoric (1st ed.). Stellenbosch, SA: Sun Press.

Mathe, A. I. (2006). Canons of classical rhetoric in Sam Nujoma's state of national addresses (1990-2004). Unpublished Masters thesis, University of the Free State, South Africa.

Mbiti, J. S. (1969). African religions and philosophy ( $\left.1^{\text {st }} e d\right)$. London: Heinemann.

Micciche, L. R. (2004). Making a case for grammatical rhetoric. College composition commmunication, 55(4), 716-737.

Micciche, L. R. (2001). The role of edited collections in composition studies. Composition: Forum: Journal of pedagogical theory in rhetoric and composition, 12(3), 101-124.

Mwangi, C. W. (2009). A rhetorical analysis of African unification oratory. Unpublished doctoral dissertation, National University of Lesotho.

Nordquist, R. (2017). Arrangement in composition and rhetoric. Retrieved May 22, 2018 from https://www.thoughtco.com

Orwell. G. (1946). Animal Farm. London: Penguin Group.

Steinberg, S. (1999). Persuasive communication skills: Public speaking. Cape Town: Juta.

Tutu, D. M. (1983). Hope and suffering: Sermon and speeches. Johannesburg: Skotaville Publishers. 